\title{
ENGINEERING STUDIES ON GRADING OF ORANGE
}

\author{
Abd El Azeem, I. ; A. Helal ${ }^{* *}$; A. Derbala ${ }^{* * *}$; \\ M. Abd-El Rahman ${ }^{* * * * *}$ and T. Fouda ${ }^{*}$
}

\begin{abstract}
This work was carried out to study some physical and mechanical properties of orange Navel variety, develop, construct and test of small grading machine for horticultural crops suitable for the small Egyptian farms. To evaluate the performance of the modified grading machine, some engineering factors were studied. These factors were feeding conveyor speeds $(0.20,0.25,0.30$ and $0.35 \mathrm{~m} / \mathrm{s})$, grading belts speeds $(0.30,0.40,0.50$ and $0.60 \mathrm{~m} / \mathrm{s})$ and grading belts at slope angle (zero deg.). Efficiency indicators such as grading efficiency, machine capacity, power and energy requirements and total mechanical damage were measured and calculated. The obtained results can be summarized as follows: Physical properties of Navel orange were $61.5-85.6 \mathrm{~mm}$ (length), $61.6-85.9 \mathrm{~mm}$ (width), $114-295 \mathrm{~g}$ (weight), $130-320 \mathrm{~mm}^{3}$ (volume) and 1.01 (sphericity). The firmness was $42.2 \mathrm{~N}$, the rolling angle was $13.12 \mathrm{deg}$. and the friction angle values were 15 and $11.55 \mathrm{deg}$. for rubber and metal, respectively. The minimum and maximum grading capacity values were $2.721 \mathrm{t} / \mathrm{h}$ and $3.817 \mathrm{t} / \mathrm{h}$ at $0.20,0.30$ and $0.35,0.60$ $\mathrm{m} / \mathrm{s}$ of feeding conveyor and grading belts speeds, respectively for Navel variety. The total mechanical damage values were $0.115 \%$ and $0.304 \%$ as min. and max., respectively. The minimum machine grading efficiency values were $81.4 \%$ and $95.8 \%$ as min. and max., respectively. The energy requirements were $7.5 \mathrm{~kW} . \mathrm{h} / \mathrm{t}$ and $0.153 \mathrm{~kW} . \mathrm{h} / \mathrm{t}$ for manual and mechanical grading, respectively. The results indicated that fruit feeding conveyor speed $(0.20 \mathrm{~m} / \mathrm{s})$, grading belts speed $(0.30 \mathrm{~m} / \mathrm{s})$ and zero deg. of grading belts slope angle during grading of orange produced maximum grading efficiency (95.8\%) and permissible mechanical damage (0.115\%).
\end{abstract}

Keywords: Physical properties, mechanical properties, orange grading machine, energy and efficiency

\footnotetext{
${ }^{*}$ Assis. Researcher, Agric., Eng., Rese., Institute, Doky, Giza

${ }^{* * *)}$ Asso. Prof., Agric. Eng. Dept., Fac. of Agric., Tanta University

${ }^{* * * *)}$ Prof. of Agric. Eng., Agric. Eng. Dept., Fac. of Agric., Tanta University

${ }^{* * * * *)}$ Head of Rese. Agric., Eng., Rese., Institute, Doky, Giza
} 


\section{INTRODUCTION}

$\mathrm{n}$ Egypt, the total cultivated area of orange is about (68461.5 feedan)
and produced about 1.2 million ton of orange (Ministry of
Agriculture and Land Reclamation, 2013). Grading of fruits and vegetables is an important operation affecting quality, handling and storage of produce. The design of the sorter with fruits rolling on a moving belt in front of different gates, apples of regular shape were sorted with greater accuracy than those of irregular shape Dobrza and Rybczy (2000). The high correlation between maximum fruit dimension and mass suggests that to use as alternative sorting criterion. Jaren and GarciaPardo (2002) mentioned that there is no clear definition of fruit quality. Many quality factors such as size, shape, color, flavor, firmness and taste are related to ripeness. Since many quality factors of agricultural products are related to their physical properties, it is necessary to develop nondestructive techniques to evaluate post-harvest ripeness based on these physical properties. Anonymous (2003) designed and developed a divergent roller type of onion grader to separate of onion based on size. The roller with spacing of $35-80 \mathrm{~mm}$ from feed end to discharge end between the rollers. The capacity of the grader was $500 \mathrm{~kg} / \mathrm{h}$. Anonymous (2004) designated three grades based on size and these grades were > 60mm (large), 40-60mm (medium) and 20- 40mm (small). Tabatabaeefar and Rajabipour (2005) mentioned that for agricultural materials, volume, mass and projected areas are the most important ones in sizing systems. They reported that to design a machine for handling, cleaning, conveying, and storing, the physical, mechanical and hydraulic properties of agricultural products must be known. Topuz, et al. (2005) studied the physical and nutritional properties of four varieties of orange. They presented data on dimensions, volume, mean geometrical diameter, surface area, fruit density, pile density, porosity, packaging coefficient, and friction coefficient. Ashraf, et al. (2007) designed, developed and evaluated the performance of fruit and vegetable grader. Yehia, et al. (2009) studied mechanical properties of Ponkan mandarin: The average of firmness distribution along the surface of mandarin were $11 \mathrm{~N} / \mathrm{cm}^{2}$ and $18.3 \mathrm{~N} / \mathrm{cm}^{2}$ as min. and max., at the bottom and top of fruit, respectively. Dhineshkumar andSiddharth (2015) studied some physical properties 
of orange and they investigated that, grade one (large), two (medium) and three (small). These properties included: dimensions, mass, volume, surface area, porosity and coefficient of static friction. The major intermediate and the minor diameters of the grade two were 87.4 and $76.91 \mathrm{~mm}$, respectively. They concluded that the three classes of oranges were significantly different from each other regarding their physical properties. Mazidi, et al. (2016) reported that the mechanical damage during packaging can be determined by study of firmness changes of fruit.

The main objectives of this work were to study some physical and mechanical properties of Navel orange variety, develop, construct and evaluate of small grading machine for horticultural crops suitable for the small Egyptian farms.

\section{MATERIALS AND METHODS}

This research work was carried out at Agric. Eng. Dept., Faculty of Agriculture, Tanta University, Egypt. To achieve the aim of this study, Navel orange variety was selected. Four different feeding conveyor speeds $0.20,0.25,0.30$ and $0.35 \mathrm{~m} / \mathrm{s}$ were used. Four different grading belts speeds $0.30,0.40,0.50$ and $0.60 \mathrm{~m} / \mathrm{s}$ were chosen. One slope for the grading belts zero was tested.

\section{Developed machine:}

Fig. 1. Shows the construction of the developed machine as follows:

Frame: Constructed from steel angle $(40 \mathrm{x} 40 \mathrm{~mm}) 5 \mathrm{~mm}$ thick. The frame dimensions were $3000 \mathrm{~mm}$ length, $700 \mathrm{~mm}$ width and $900 \mathrm{~mm}$ height.

Hopper (feeding box): It is made from galvanized iron sheet $(2 \mathrm{~mm}$ thick.). The main dimensions of hopper were 100 × 50 × $350 \mathrm{~mm}$ for length, width and height.

Elevator belt (transfer conveyor): The elevator belt is a flat belt $500 \mathrm{~mm}$ wide and $750 \mathrm{~mm}$ length. It is consists of an endless rubber with a scraper which are fitted with the belt.

Sorting unit: The sorting belt likes the elevator belt without scrapers. It is consists of a wide endless belt conveyor with dimensions $1000 \mathrm{~mm}$ length and $600 \mathrm{~mm}$ width. 
Grading unit: Grading unit was designed and manufactured to grade the different varieties spherical fruits and vegetables. It was consists of four belts, each one $2650 \mathrm{~mm}$ length, $17 \mathrm{~mm}$ width an $10 \mathrm{~mm}$ thickness.

Grading box: The grading box was designed and fabricated from steel sheet $1 \mathrm{~mm}$ covered by plastic sheet. It was divided to three parts to receive three sizes from grading fruits.

Power Source: Three phase electric motor (220 volt) $0.75 \mathrm{hp}(0.56 \mathrm{~kW})$ with a rotating speed of 288 r.p.m.

Figure 1: Orange grading machine

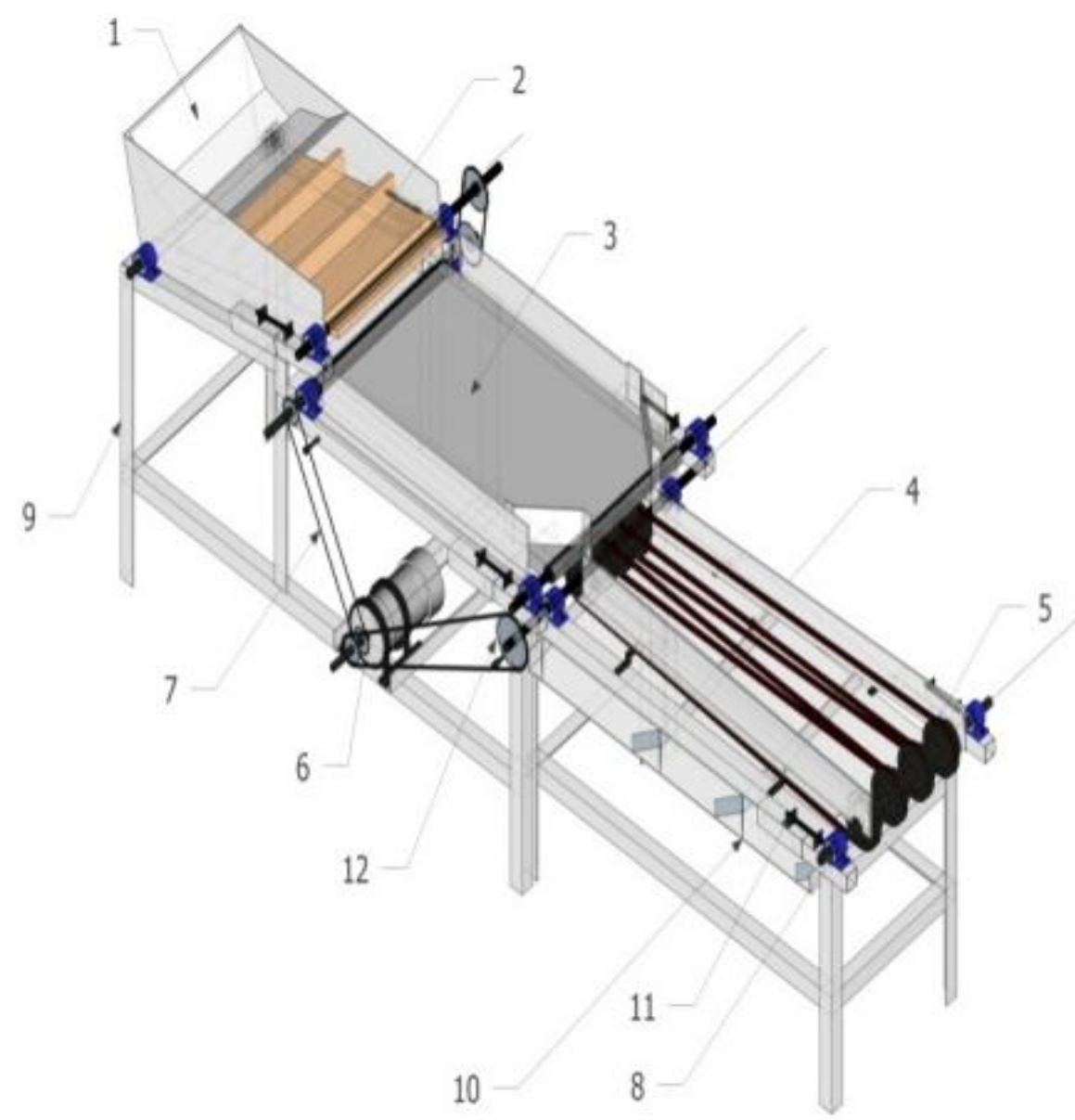

1- Hopper 2-Elevator belt 3-Sorting belt 4-Grading belts

5-Bulley 6-Electric motor 7-Chine 8-Adjustable ball bearing

9-Frame 10-Grading box 11-Guy 12-Gear 
PROCESS ENGINEERING

\section{Equations and calculations:}

According to Mohsenin (1986)

$$
S=L / W i
$$

Where:

$\mathrm{S}=$ sphericity ratio,

$\mathrm{L}=$ fruit height in $\mathrm{mm}$ and

$\mathrm{W}_{\mathrm{i}}=$ fruit diameter in $\mathrm{mm}$.

$$
d a=(L+W i) / 2
$$

Where:

$\mathrm{da}=$ arithmetic diameter in $\mathrm{mm}$,

$\mathrm{L}=$ length of fruit in $\mathrm{mm}$ and

$\mathrm{W}_{\mathrm{i}}=$ width of fruit in mm.

$$
V=w / S w
$$

Where:

$\mathrm{V}=$ volume in $\mathrm{mm}^{3}$,

$\mathrm{w}=$ weight of displaced water in $\mathrm{g}$ and

$S_{\mathrm{w}}=$ specific weight of water in $\mathrm{g} / \mathrm{mm}^{3}$.

$$
C f=\tan \theta
$$

Where:

$\mathrm{C}_{\mathrm{f}}=$ coefficient of friction

The capacity of grading machine, the efficiency of separating fruits and total grading efficiency for the developed handling machine can be calculated according to Amin (1994) as follows:

$$
G c=m i\left(\frac{60}{t}\right)
$$

Where:

$\mathrm{G}_{\mathrm{c}}=$ grading capacity in $\mathrm{t} / \mathrm{h}$,

$\mathrm{m}_{\mathrm{i}}=$ mass of classified fruits from any unit "i" in ton and

$\mathrm{t}=$ grading time in $\min$.

$$
\eta_{0}=\frac{\mathrm{mi}}{\mathrm{m}} \cdot 100
$$

Where:

$\eta_{0}=$ the grading efficiency of fruits in $\%$

$\mathrm{m}_{\mathrm{i}}=$ the mass of classified fruits from any unit "i" in ton., throughout any unit " $\mathrm{i}$ " of the machine in ton and

$\mathrm{m}=$ the total mass of fruits. 


$$
\eta=\frac{\mathrm{m} 1+\mathrm{m} 2+\mathrm{m} 3}{\mathrm{~m}} \times 100
$$

Where:

$\eta=$ total machine grading efficiency in \%,

$\mathrm{m}_{1}+\mathrm{m}_{2}+\mathrm{m}_{3}=$ average means different sizes and.

$\mathrm{m}=$ total mass of fruits in ton.

$$
E r=C p / W
$$

Where:

$\mathrm{E}_{\mathrm{r}}=$ Energy requirements in $\mathrm{kW} \cdot \mathrm{h} / \mathrm{t}$,

$\mathrm{C}_{\mathrm{p}}=$ the consumed power to handling fruits in $\mathrm{kW}$ and

$\mathrm{W}=$ grading capacity of the machine in $\mathrm{t} / \mathrm{h}$.

\section{RESULTS AND DISCUSSION}

Physical properties of orange Navel furits:

Table 1 shows dimensions, sphericity, weight and volume of Navel orange, these data were measured on 100 fruit samples, according to the standards (Mohsenin, 1986).

Table 1: Physical properties of Navel fruits

\begin{tabular}{|l|c|c|}
\hline \multicolumn{1}{|c|}{ Physical properties } & Min. & Max. \\
\hline Length $(\mathrm{mm})$ & 61.5 & 88.6 \\
\hline Width $(\mathrm{mm})$ & 61.6 & 85.9 \\
\hline Weight $(\mathrm{g})$ & 114 & 295 \\
\hline Volume $\left(\mathrm{mm}^{3}\right)$ & 130 & 320 \\
\hline Sphericity $(\%)$ & 0.88 & 1.13 \\
\hline
\end{tabular}

Table 1 indicates that the fruit length was ranged from $61.5 \mathrm{~mm}$ to 88.6 $\mathrm{mm}$. The width value was ranged from 61.6 to $85.9 \mathrm{~mm}$. In addition, the orange weight was ranged 114 to $295 \mathrm{~mm}$. Also, the fruit volume was ranged from 130 to $320 \mathrm{~mm}^{3}$. On the other hand, if sphericity is less than 0.9 , the fruit belongs to oblate group; if sphericity is greater than 1.1, it belongs to oblong group. Table 1 indicated that, the fruit sphericity ranged from 0.88 to $1.13 \%$.

\section{Mechanical properties:}

The mechanical properties such as friction angle, rolling angle, firmness and impact of Navel fruits were measured and calculated. Table 2 shows the friction angle, the rolling angle, the firmness and the impact of Navel 
orange. The maximum friction angle (15 deg.) was obtained with rubber surface and the minimum (11.55 deg.) was obtained with metal surface.

Table 2: Some of the mechanical properties of Navel orange

\begin{tabular}{|c|c|c|c|c|c|c|}
\hline \multirow{2}{*}{$\begin{array}{l}\text { Firmness, } \\
\mathrm{N} / \mathrm{mm}^{2}\end{array}$} & \multirow{2}{*}{$\begin{array}{l}\text { Rolling } \\
\text { angle, } \\
\text { degree }\end{array}$} & \multicolumn{2}{|c|}{$\begin{array}{c}\text { Fraction angle, } \\
\text { degree }\end{array}$} & \multicolumn{3}{|c|}{ Impact } \\
\hline & & Rubber & Metal & $\begin{array}{c}\text { Drop } \\
\text { height, } \\
\text { mm }\end{array}$ & $\begin{array}{c}\text { Fruit } \\
\text { bruised, } \\
\%\end{array}$ & $\begin{array}{l}\text { Percent of fruit area } \\
\text { affected, } \%\end{array}$ \\
\hline 42.20 & 13.12 & 15.00 & 11.55 & 50 to 300 & -- & -- \\
\hline
\end{tabular}

\section{Machine grading capacity:}

\section{Effect of speeds of fruit feeding conveyor}

Fig. 2 illustrated that when the feeding conveyor speed increased during the grading process of orange from 0.20 to $0.35 \mathrm{~m} / \mathrm{s}$ at all grading belts speeds in the range of 0.30 to $0.60 \mathrm{~m} / \mathrm{s}$ and at all grading belts slope angles in the range of zero to $9 \mathrm{deg}$., cause a corresponding increase in the machine grading capacity.

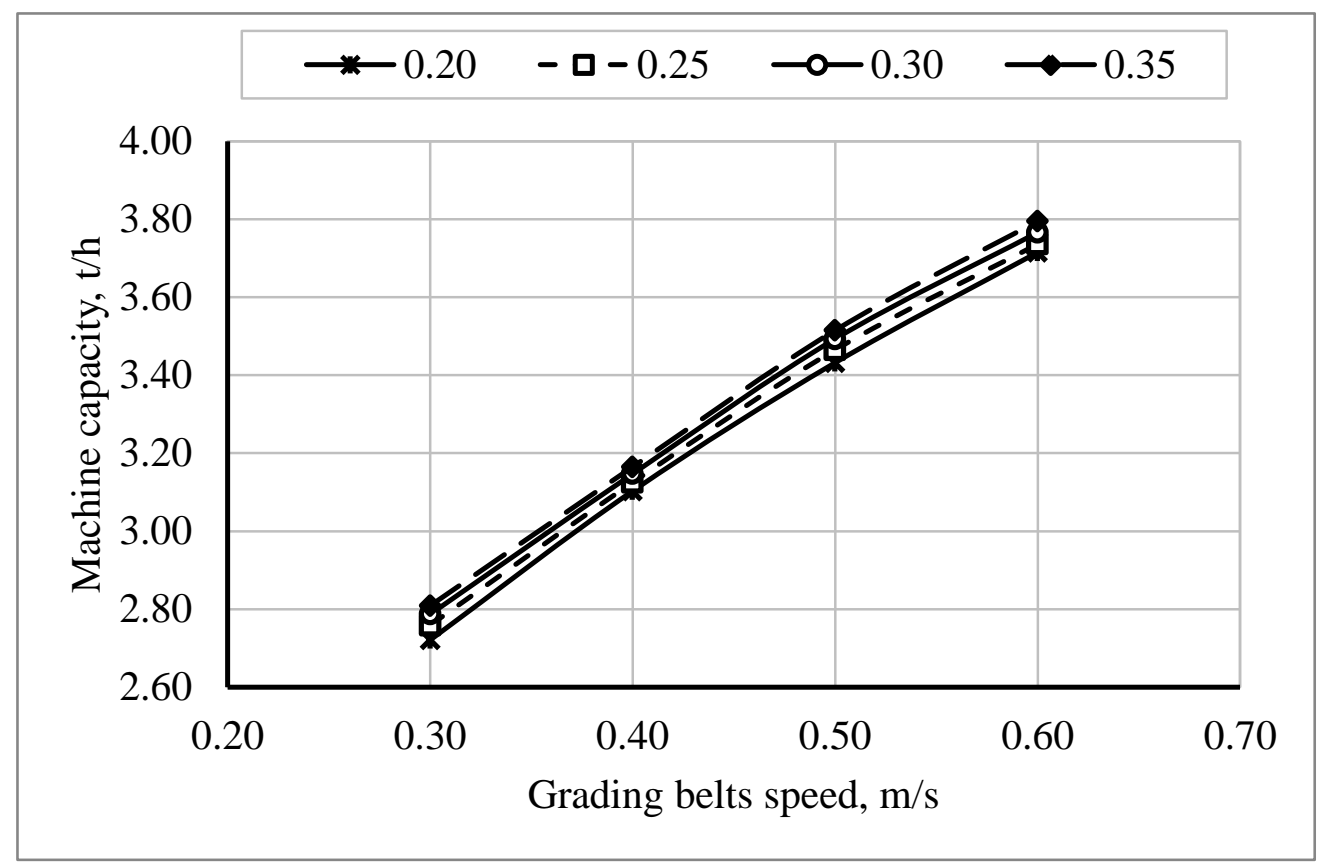

Fig. 2: Effect of grading belts and feeding conveyer speeds on the machine capacity at zero grading belts slope 
The minimum machine grading capacity value $2.721 \mathrm{t} / \mathrm{h}$ obtained from $0.20 \mathrm{~m} / \mathrm{s}$ of fruit feeding conveyor speed at $0.30 \mathrm{~m} / \mathrm{s}$ grading belts speed and zero deg. of grading belts slope. The maximum machine grading capacity value $3.817 \mathrm{t} / \mathrm{h}$ obtained from $0.35 \mathrm{~m} / \mathrm{s}$ of fruit feeding conveyor speed at $0.60 \mathrm{~m} / \mathrm{s}$ grading belts speed and $9 \mathrm{deg}$. of grading belts slope.

\section{Mechanical damage percentage:}

It can be seen from Fig.3 that increasing the speed of fruit feeding conveyor at any grading belts speed in range of 0.30 to $0.60 \mathrm{~m} / \mathrm{s}$ and all grading belts slopes in the range of zero deg. to $9 \mathrm{deg}$. cause a corresponding increase in the mechanical damage of orange. It can also be seen that for grading belts speed of $0.30 \mathrm{~m} / \mathrm{s}$ and grading belts slope of zero deg. mechanical damage of orange ranged from 0.115 to $0.135 \%$ as the feeding conveyor speed increased from 0.20 to $0.25 \mathrm{~m} / \mathrm{s}$. The minimum mechanical damage value $0.115 \%$ obtained from $0.20 \mathrm{~m} / \mathrm{s}$ of feeding conveyor speed at $0.30 \mathrm{~m} / \mathrm{s}$ grading belts speed and zero degree of grading belts slope. The maximum mechanical damage value $0.304 \%$ obtained from $0.35 \mathrm{~m} / \mathrm{s}$ of fruit feeding conveyor speed at $0.60 \mathrm{~m} / \mathrm{s}$ grading belts speed and $9 \mathrm{deg}$. of grading belts slope.

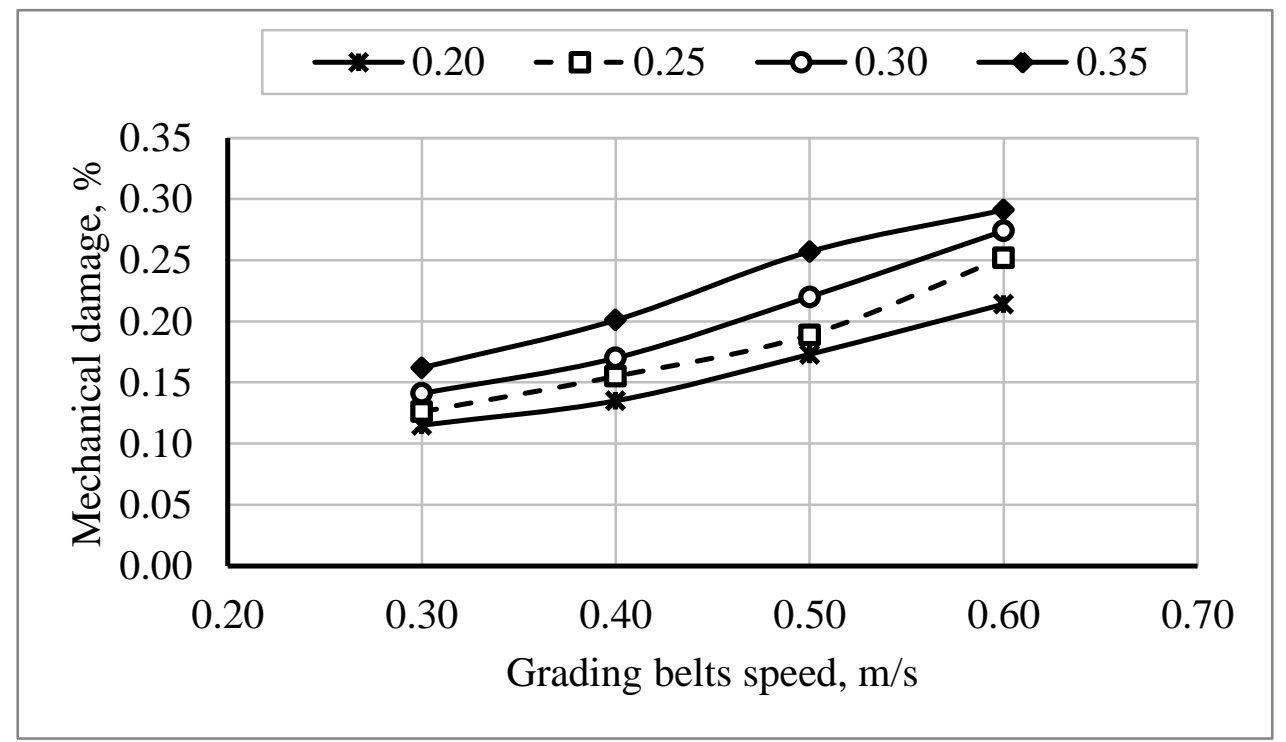

Fig. 3: Effect of grading belts and feeding conveyer speeds on the mechanical damage at zero grading belts slope 


\section{Machine grading efficiency:}

Fig. 4 show that the increasing of fruit feeding conveyor speed from 0.20 to $0.35 \mathrm{~m} / \mathrm{s}$ at all grading belts speeds in range 0.30 to $0.60 \mathrm{~m} / \mathrm{s}$ and at all grading belts slopes in range of zero to $9 \mathrm{deg}$. cause a corresponding decrease in the machine grading efficiency.

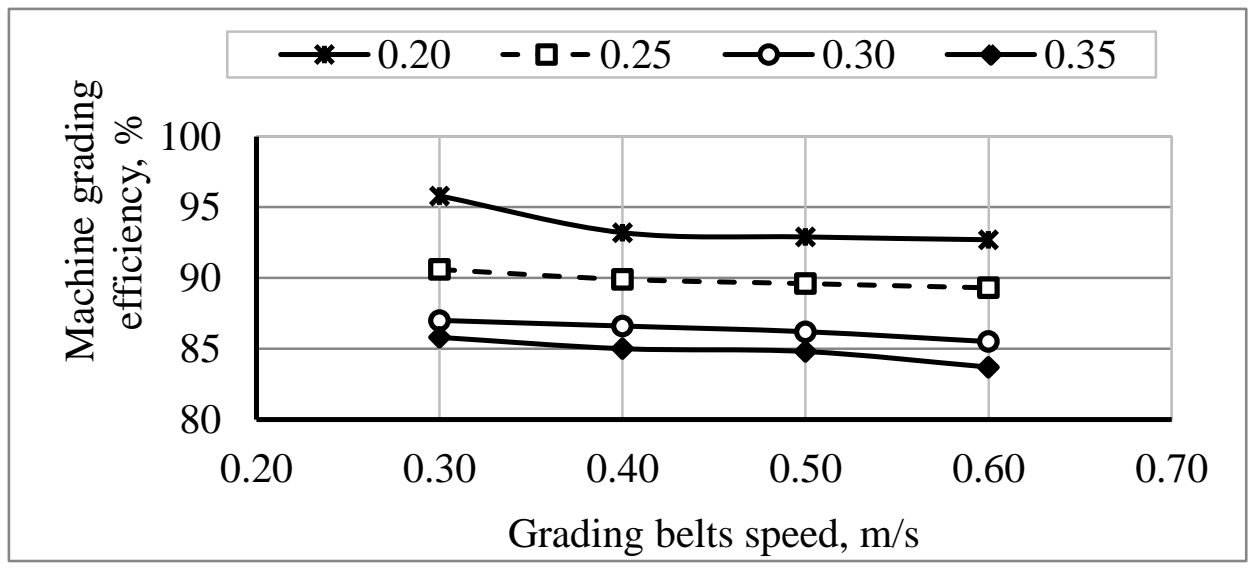

Fig. 4: Effect of feeding conveyor speed, grading belts speed and grading belts slope on machine grading efficiency

\section{Power and energy requirements:}

It can be seen from Figs. 5 and 6 that for grading belts speed of $0.30 \mathrm{~m} / \mathrm{s}$ the power loaded and useful power for oranges ranged from 0.419 to $0.480 \mathrm{~kW}$ and from 0.012 to $0.024 \mathrm{~kW}$, respectively as the feeding conveyor speed increased from 0.20 to $0.35 \mathrm{~m} / \mathrm{s}$.

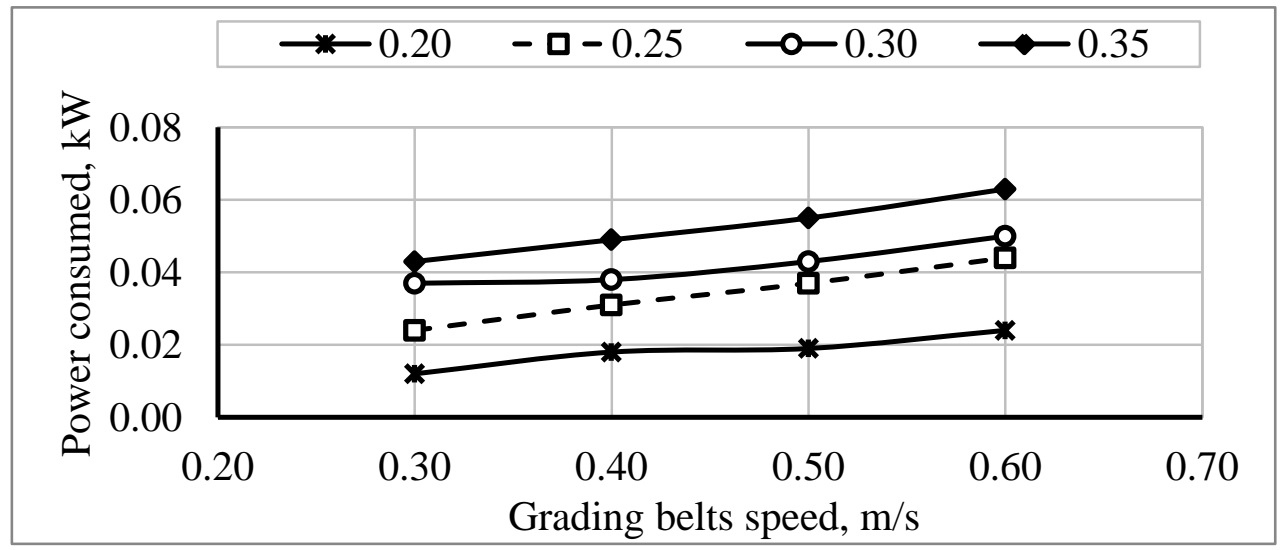

Fig. 5: Effect of feeding conveyor and grading belts speeds on the power consumed 


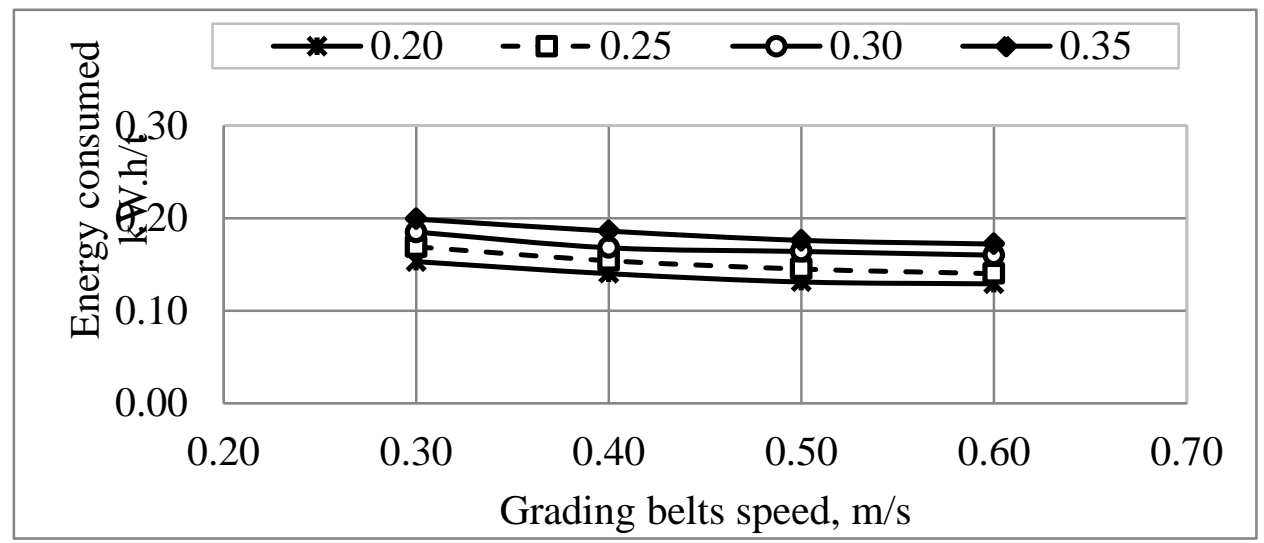

Fig. 6: Effect of feeding conveyor and grading belts speeds on the energy requirements

It can be seen also that for grading belts speeds of $0.30 \mathrm{~m} / \mathrm{s}$ the energy consumed ranged from 0.153 to $0.129 \mathrm{~kW} . \mathrm{h} / \mathrm{t}$. This decrease in energy consumed by increasing the feeding conveyor speed may be due to the increase machine capacity.

\section{CONCLUSION}

Laboratory measurements were carried out to determine physical and mechanical properties of Navel orange variety. The collected data takes as a fundamental basic to introduce the most suitable engineering parameters for develop, construct and test a small grading machine for horticultural crops suitable for the small Egyptian farms. The optimum operation parameters for the modified orange grading machine were $0.20 \mathrm{~m} / \mathrm{s}$ of feeding conveyor speed, $0.30 \mathrm{~m} / \mathrm{s}$ grading belts speed and zero deg. of grading belts slope angle, which produced maximum grading efficiency of $95.8 \%$, permissible mechanical damage of $0.115 \%$ and capacity of $2.721 \mathrm{t} / \mathrm{h}$ and energy of $0.153 \mathrm{~kW}$. h/t for Navel orange variety.

\section{REFERENCES}

Amin, E. A. (1994): Development of grading machine for some Egyptian farm crops. J. Agric. Sci., Mansoura Univ., 19(7):(2398 - 2411).

Anonymous (2003): Design and development of divergent roller type onion grader.Rajgurunagar, Pune. Technical bulletin No. 6.

Anonymous (2004): Agriculture statistics of Pakistan, 2003-04. Federal Bureau of Statistic's Islamabad Pakistan.

Ashraf, M.; S. S. Muhammad; A. Manzoor and Y. Muhammad (2007): Design, development and performance evaluation of fruit and vegetable grader. Pak. J. Agri. Sci., 44(4):704-713. 
Dhineshkumar, V. and M. Siddharth (2015): Studies on physical properties of orange fruit. Journal of Food Research and Technology, 3(4):125-130.

Dobrza, S. B. and S. R. Rybczy (2000): A sorting line for uality grading of apple. Zemes KioInzininerija, MoksloDarbai, 32(3):195 - 202.

Jaren, C. and E. Garecia-Pardo (2002): Using non-destructive impact testing for sorting fruits.Journal of food Engineering, 53:89-95.

Mazidi, M., H. Sadrnia and M. Khojastehpour (2016): Evaluation of orange Research Journal, 23(2):899-903.

Ministry of Agricultural and Land Reclamation, Arab Republic of Egypt, Economic Affairs Sector (2013): Bulletin of the agricultural statistics part 12 winter crops 2011/2012.

Mohsenin, N.N., (1986): Physical properties of plant and animal materials. Gordon and Breach Science Publishers, pp 20-89.

Tabatabaeefar, A. and A. Rajabipour (2005): Modeling the mass of apples by geometrical attributes. Sci. Horticultural Journal, 105:373-382.

Topuz, A.; M. Topakci; M. Canakci; I. Akinci and F. Ozdemir (2005): Physical and nutritional properties of four orange varieties. J. Food Eng. Res., 66:519-523.

Yehia, I.; M. H. Kabeel and M. M. Abdel Galeel (2009): Physical and mechanical properties of Mandarin applied to grading machine. Misr J. of Ag. Eng., 26(2):1036-1053.

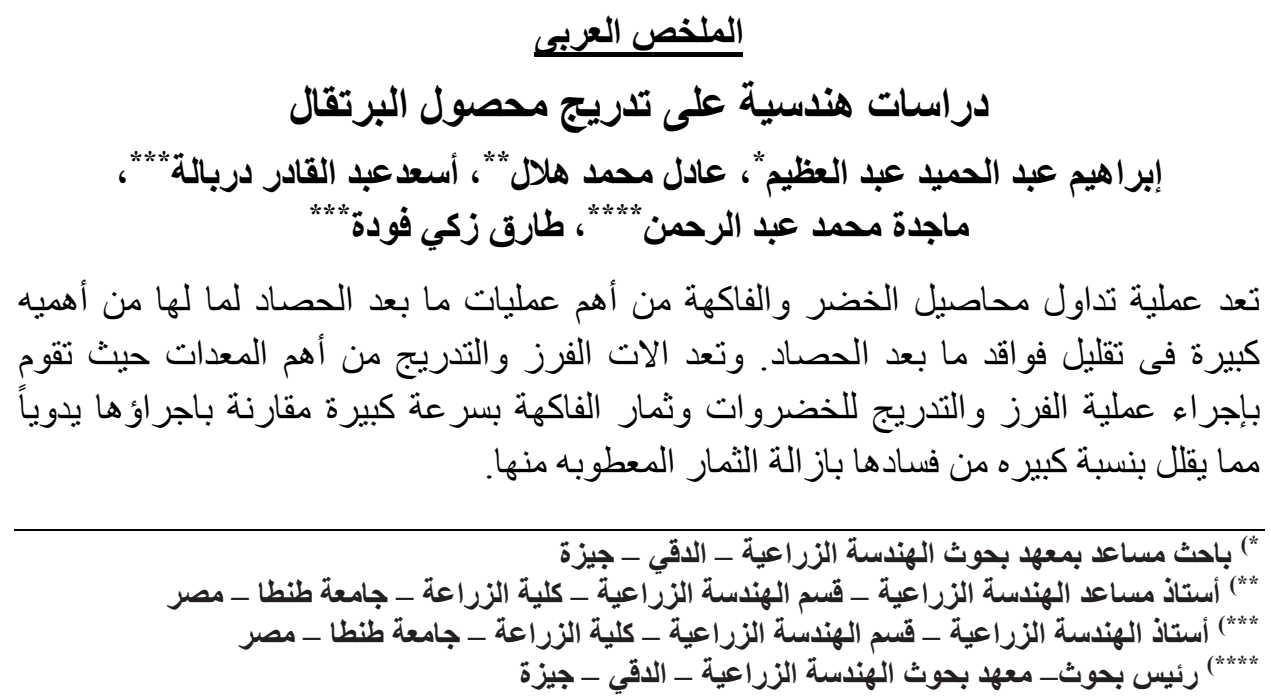


هذا يتيح للمنتج بيعها فى الاسواق بأسعار مرتفعة وبذلك يزيد من دخله. يهذف البحث النطوير

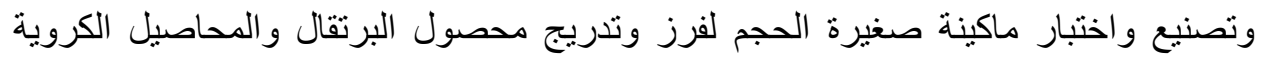

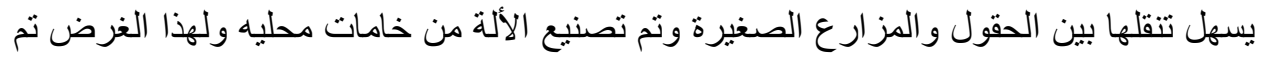
در اسة بعض الخو اص الطبيعية و الميكانيكية لثمار البرتقال.

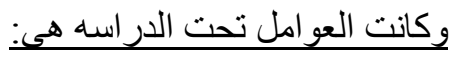

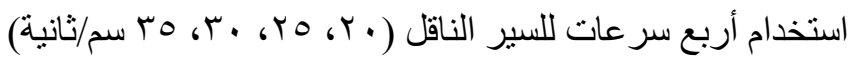

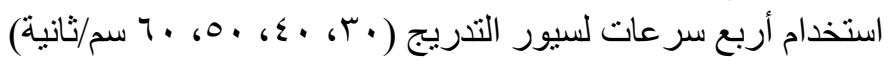

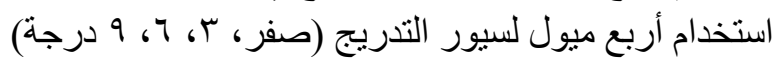
وكانت مؤشرات الكفاءة هي:

الخواص الطبيعيه لثمار البرتقال (الأبعاد- الوزن - الحجم- الكروية).

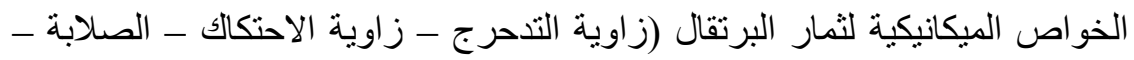

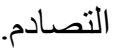
نسبة التحطم الميكانيكى - سعة الآلة ـ كفاءة الآلة ـ الطاقة المستهلكة. وخلصت الدر اسة إلى:

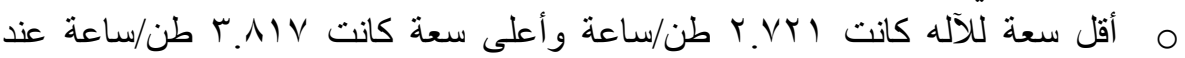

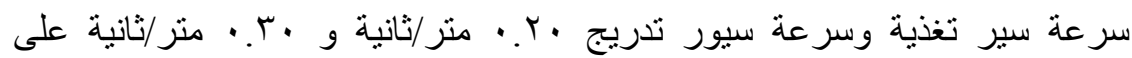
الترتيب.

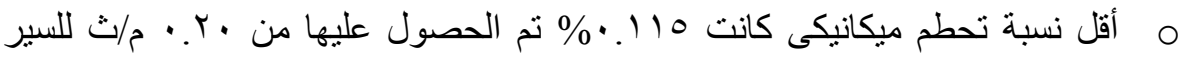

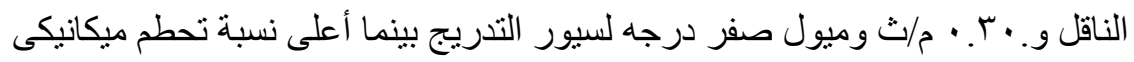

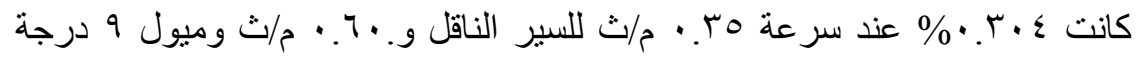
لـيور التنريج.

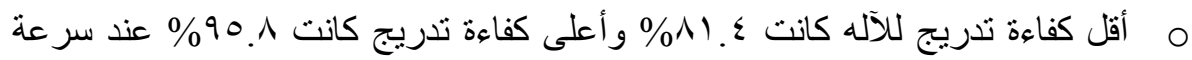

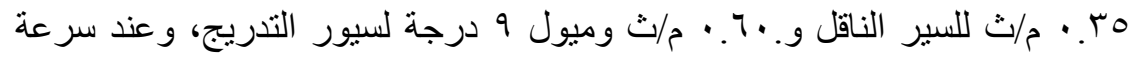

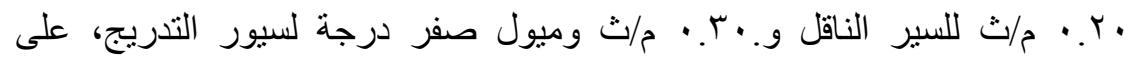
الترتيب.

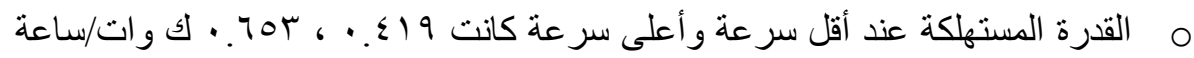

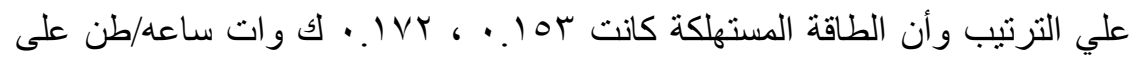
الترتيب.

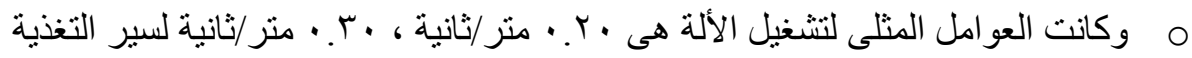
وسيور التدريج على الترتيب وميول صفر لسيور التدريج. 